Table 3. Relation of available calcium and incidence of rickets to extraction rate and fortification level of flour

\begin{tabular}{|c|c|c|c|c|}
\hline $\begin{array}{l}\text { Dates when changes } \\
\text { made and surveys } \\
\text { carried out }\end{array}$ & $\begin{array}{l}\text { Extraction } \\
\text { rate of } \\
\text { flour }\end{array}$ & $\begin{array}{c}\text { Added } \\
\text { calcium } \\
\text { (mg./oz. bread) }\end{array}$ & $\begin{array}{c}\text { Available } \\
\text { calcium* } \\
\text { (mg./oz. bread) }\end{array}$ & $\begin{array}{c}\text { Incidence } \\
\text { of rickets } \\
\text { per } 1000 \text { in } \\
\text { children over } \\
\text { I year }\end{array}$ \\
\hline Up to Sept. 1940 & 70 & $\circ$ & $5 \cdot 7$ & - \\
\hline Sept. 1940 & 75 & $\circ$ & $5 \cdot 3$ & - \\
\hline Jan. 1941 & 80 & 0 & 3.4 & - \\
\hline Feb. I94 I & 90 & 。 & $-1 \cdot 4$ & - \\
\hline Mar. 1941 & 95 & $\circ$ & $-6 \cdot 0$ & - \\
\hline Feb. 1942 & 100 & $\circ$ & $-11 \cdot 0$ & - \\
\hline Feb. to Apr. 1943 & 100 & 0 & $-11 \cdot 0$ & 172 \\
\hline Dec. 1943 & 85 & $\circ$ & $2 \cdot 4$ & - \\
\hline Feb. to Apr. 1944 & 85 & $\circ$ & $2 \cdot 4$ & 139 \\
\hline Feb. to Apr. 1945 & 85 & 0 & $2 \cdot 4$ & 79 \\
\hline Nov. 1945 & 80 & 0 & 3.4 & - \\
\hline Feb. 1946 & 85 & $\circ$ & $2 \cdot 4$ & - \\
\hline Feb. to Apr. 1946 & 85 & o & $2 \cdot 4$ & 85 \\
\hline Apr. 1946 & 90 & 0 & $-1 \cdot 4$ & - \\
\hline June 1946 & 90 & 19 & $17 \cdot 6$ & - \\
\hline Nov. 1946 & 90 & 10 & $8 \cdot 6$ & - \\
\hline Jan. 1947 & 85 & 10 & $12 \cdot 4$ & - \\
\hline Feb. to Apr. $19+7$ & 85 & 10 & $12 \cdot 4$ & 47 \\
\hline Feb. to Apr. 1948 & 85 & 10 & 12.4 & 27 \\
\hline
\end{tabular}

- Calculated on the assumption that calcium bound as hexacalcium phytate is not available.

The various surveys were carried out with the aid of grants from the Medical Research Council of Ireland, the Medical Association of Eire and the Marrowbone Lane Samaritan Fund.

\title{
REFERINCES
}

Croasdaile, H. V., Collis, W. R. F., Pringle, H. \& Jessop, W. J. E. (1943). J. med. Ass., Eire, 12, 69. Epstein, M. R., Kidney, W., Collis, W. R. F., Pringle, H., Reynolds, R. A., Douglas, S. \& Jessop, W. J. E. (1950). F. med. Ass., Eire, 26, 19.

Fitzgerald, H. D., Sheehan, N. E., Collis, W. R. F., Pringle, H., Reynolds, R. A. \& Jessop, W. J. E. (1944). F. med. Ass., Eire, 15, 54 .

Grove-White, M. L., Sheehan, N. E., Collis, W. R. F., Pringle, H., Reynolds, R. A., Douglas, S. \& Jessop, W. J. E. (1945). Y. med. Ass., Fire, 17, 159.

Harrison, D. C. \& Mellanby, E. (1939): Biochem. F. 33, 1660.

McCance, R. A. \& Widdowson, E. M. (1942-3). Y. Physiol. ror, 44.

Pringle, H., Reynolds, A. A. \& Jessop, W. J. E. (1943). J. med. Ass., Eire, 12, 67.

Walsh, J. P., Kidney, W., Collis, W. R. F., Pringle, H., Reynolds, R. A., Douglas, S. \& Jessop, W. J. E. (1946). 9. med. Ass., Eire, 19, 156.

\section{Practical Significance of the Irish National Nutrition Survey}

By J. Deeny (Chief Medical Adviser, Department of Health, Government of Ireland), Customs House, Dublin

I shall commence these remarks with the trite observation that the administrative approach to a survey such as the Irish National Nutrition Survey (Department of Health (Republic of Ireland), 1949a, $b, 195 \circ a, b$ ) is very different from that of the investigator or nutritional specialist. Whereas it is the task of the research worker or investigator 
to demonstrate or ascertain facts, it becomes the responsibility of the medical administrator or adviser to elaborate, apply or recommend the application of measures based on such data. This part of nutrition work is really far more difficult than any other and this can be easily recognized. It can be measured by what is being done, against what could or should be done in the matter of ensuring a satisfactory diet for everyone.

When making some preliminary notes for these remarks I found that I was writing down 'providing a satisfactory diet for everyone' but stroked it out, replacing it by the word 'ensuring'. In doing so the thought struck me that I should say something about this country's approach to nutrition. The difference between 'providing' and 'ensuring' adequate diets assumes serious significance here. For instance, in many countries during the last decade the provision of an adequate diet came to be regarded as the responsibility of government. 'This has been necessary for many reasons, but unfortunately the provision of an adequate diet for everyone has been coupled with control over people's labour, business affairs, lives and freedom generally.

In this country, where freedom and liberty are prized, any administrative action in nutrition must be conditioned by the national dislike of regimentation or control. On the other hand, the lessons learnt during the last decade by successful controlled and planned food policies cannot be neglected. There is no properly organized national economy which can avoid completely some of the elements of a planned economy.

Accordingly it must be appreciated that here in Ireland and in relation to this survey, though we may go a certain way in applying food rations or controls to the general population, we cannot go as far as many other countries. That is, of course, apart from any difficulties which the nature or composition of our population provides. After all, a country in which half the population are farmers and well fed on home produce is very difficult to ration, even if it were proposed to introduce such rationing.

The National Survey from the practical viewpoint has first of all given us a defined picture of the food situation in this country, which we had not before. We now know in a reasonably definite way things which before may have been surmised or vaguely appreciated, but without any certainty. We know the vulnerable groups and the features of diet which they lack. We know how far we have to go to ensure an adequate diet for these groups. We now have facts and figures on which to argue, and though these may take some of the adventure and interest out of a really hearty Irish controversy, there is no doubt that they help in arriving at conclusions.

To take this survey as a whole, so far as we have gone, it may be stated that it shows that roughly half the population, the 600,000 farm families, of Ireland have enough or more than enough to eat. It seems to me that the results obtained in the study of farm families in Section IV, National Nutrition Survey (Department of Health (Republic of Ireland), $195^{\circ} b$ ) should cause us to question the standards used. If the requirements of the farm families are adequately met, the League of Nations standard may be too low. I personally feel that much more work should be undertaken on standards relating the intake required to the amount of work done by the individual. The Survey also shows for the other half of the Irish population, that the majority of dwellers in the towns or in Dublin are adequately satisfied and consume a reasonable diet. Now these results are very satisfactory, but they do give rise to a difficulty which is the fact that so many 
people are so well fed that it makes it difficult to make nutrition a real issue for the few not so well nourished.

In this country much has had to be done. For instance, in 1922 we had not one modern hospital building. In Dublin there were 80,000 families living in one-room dwellings. 'The Irish mud-cabin was a familiar object. The problem of eradicating tuberculosis remained as a national target, and nutrition took a relatively low place in the list of jobs to be tackled on a national scale. Also, until this survey was carried out we had nothing really to go on.

Let us take some of the dietary deficiencies revealed by the survey. In Dublin calcium intake is deficient, particularly in the larger families. Now in facing this problem there are certain points. The best remedy for this deficiency is to increase milk consumption. There is no shortage of supply and with improved agricultural conditions the milk supply for Dublin has increased to such an extent that producers have recently begun a campaign of advertising to induce people to drink more milk. In view of the findings of the survey, it is apparent that some cannot afford to buy sufficient milk. However, under our Infant Aid Scheme there is no child in this city under 5 requiring milk who cannot get it free. I would point out also that all the milk given in the school meals is not consumed. I feel personally that there is no short-cut in this city as regards calcium. There is no doubt that the services already provided are not fully utilized. Look at the rickets problem and then consider that there are literally dozens of centres and dispensaries where mothers can get free cod-liver oil or other preparations. I should mention that there is no ceiling on expenditure in these services. In the matter of food, particularly calcium, in large families, while the question of improving the milk supply is constantly under review, other means of helping are being elaborated. For instance, after I June a system of differential rents will come into force in the 25,000 houses owned by the Corporation. Family allowances are paid, the new Social Welfare proposals are taking into account large families, and through the existing services of free boots for necessitous children, free fuel, free meals, running into millions each year, through the Catholic Social Service Conference, by relieving distress in other ways, efforts are being made to ensure an adequate diet for everyone. The deficiency of calcium can in my opinion be countered best by a policy of education, social improvement, increased efficiency in the dairy industry, family assistance and, a long way behind for the small group who cannot be helped any other way, a further extension of our free or cheap milk scheme.

In the congested rural districts there is a monotony of diet, but again the answer lies in agricultural and economic improvement. The Government has introduced a Land Reclamation Scheme in which $£_{4} 0$ million is to be spent on draining bogs and marshes, fertilizing poor land and reseeding vast areas; minor schemes such as grants for tomato houses, a scheme of Parish Advisory Agricultural Agents and many other measures are being organized. The question of cooking is being assisted by rural electrification.

The Gaeltacht diet is extremely nutritious. It is a diet that has been evolved on a principle of survival. It suits these areas and if it were made more uniform throughout the year it would be excellent. When Dr Hourihane (1950) speaks of a bread and 
spread or cooked meal there is a vast difference between the loaves of golden-brown wholemeal bread, the great lumps of orange-coloured butter, the thick brown-shelled eggs and the creamy milk of so many Gaeltacht homes and that of the city bread and spread meal, even here in Dublin. Tinkering with relatively primitive diets must be gentle. It must be in accordance with natural biological principles and must not replace home-grown foods produced by home labour by factory goods, with a resultant decay in husbandry.

This survey must also be read in terms of the natural frugality of the Irish people, who are extremely simple and conservative in their food tastes.

\section{Conclusions}

We know now that generally the people of this country are very well fed; that there are small groups of poor persons, particularly those in large families in cities and towns, whose diet is defective in some respects and often monotonous. Efforts to improve our national dietary therefore fall into two categories: (I) relatively small short-term efforts to counteract specific deficiencies in small population groups, and (2) large-scale projects on a long-term basis to improve the general living standards of the people by increased productivity and purchasing power and by improved social amenities.

It is clear that our efforts to improve social conditions have been on lines also calculated to assist the nutritional state of the population. It seems also reasonable to suppose that, granted stable conditions and without complacency about our present circumstances, further progress along our present lines will enable us to ameliorate any dietary deficiencies which exist in our vulnerable population groups.

\section{REFERENCES}

Department of Health (Republic of Ireland) (1949a). Methods of Dietary Survey and Results from Dublin Investigation. Dublin: The Stationery Office.

Department of Health (Republic of Ireland) (1949b). Dietary Survey of the Congested Districts. Dublin: The Stationery Office.

Department of Health (Republic of Ireland) (1950a). Dietary Survey of Large and Small Towns. Dublin: The Stationery Office.

Department of Health (Republic of Ireland) (1950b). Dietary Survey of Farming Families. Dublin: The Stationery Office.

Hourihane, J. D. (1950). Brit. F. Nutrit. 4, 270. 